\title{
Nitrogen mass balance in waste stabilization ponds at the University of Dar es Salaam, Tanzania
}

\author{
Aloyce W. Mayo \\ Department of Water Resources Engineering, University of Dar es Salaam, P.O. Box 35131, Dar es Salaam, Tanzania.
}

Accepted 1 August, 2013

\begin{abstract}
Nitrogen mass balance in waste stabilization pond system at the University of Dar es Salaam was determined using a dynamic mathematical model in order to elucidate the biological nitrogen transformation mechanisms that are effective for removal of nitrogen in this pond system. Results show that the pond system removed $4741 \mathrm{~g} /$ day of nitrogen from an influent load of $8036 \mathrm{~kg} / \mathrm{day}$, which is equivalent to $59 \%$ removal efficiency. The overall dominant nitrogen removal mechanism was denitrification, which was responsible for $77.5 \%$ of the removed nitrogen. Other permanent nitrogen removal mechanisms were net loss of nitrogen to sediments and volatilization, which contributed 18.2 and $4.3 \%$ of the removed nitrogen, respectively. However, sedimentation was the major nitrogen removal mechanism in primary facultative pond, which was responsible for $73.7 \%$ of the total nitrogen removed in that pond. On the other hand, denitrification was the major nitrogen removal mechanism in secondary facultative ponds (F2 and F3) and maturation pond, M, which contributed about 95.0, 89.4 and $89.1 \%$ of the total nitrogen removed from these ponds, respectively. The major nitrogen transformation routes were mineralization and ammonia uptake in the primary facultative pond F1. In secondary facultative pond F2, nitrification and denitrification were the dominant nitrogen transformation mechanisms, while in secondary facultative pond $\mathrm{F} 3$ and maturation pond $\mathrm{M}$, ammonia uptake was the dominant transformation route. The results obtained in this work may be used as a management tool in assessing the levels of nitrogen compounds in waste stabilization ponds and thus protect the water bodies downstream.
\end{abstract}

Key words: Nitrogen dynamics, waste stabilization ponds, nitrogen removal, mathematical modeling.

\section{INTRODUCTION}

Wastewater stabilization pond treatment technology has been used for removal of organic matter (Zimmo et al., 2005; Mugasa, 2005; Barrie, 2002), pathogenic organisms (Mayo, 1995; Kalibbala, 2001; Osman, 1998) and nutrients particularly nitrogen (Hanai, 2006; Alahmady et al., 2013; Rockne and Brezonik, 2006). This technology can be used for treatment of wastewater from domestic, industrial and agricultural sources (Hanai, 2006; Tadesse et al., 2004; Al-Sa'ed, 2007; Sedlack, 1991). Waste stabilization ponds are largely used in tropical climates (Mayo, 1995; Mara, 2005) although their application in temperate climatic region with temperatures as low as $7^{\circ} \mathrm{C}$ is not uncommon (Rockne and Brezonik, 2006). However, in cold climates, wastewater is applied at very low organic loading rates of less than $60 \mathrm{kgBOD}_{5} / \mathrm{ha} /$ day (Faleschini et al., 2012) and wastewater may be retained for a duration of up to one year (Krkosek et al., 2012).

The major advantages of waste stabilization pond technology include removal of pathogenic organisms without addition of chemicals, low sensitivity to hydraulic and organic shock loads, low construction, operation and maintenance costs, minimum or no mechanical equip- 
ment is required for their operation and low requirement of external source of energy (Mayo, 1995; Shilton and Walmsley, 2005; Isosaari et al., 2010). However, pond technology suffers stability problems with effluent concentrations because of large amount of biomass in the effluent and large land requirement (Isosaari et al., 2010; Vera et al., 2013).

As a result, improvement of effluent from waste stabilization ponds is desirable through rock filters and constructed wetland systems (Manyama, 2005; Mara and Johnson, 2006; Al-Sa'ed et al., 2011). Other efforts to improve nutrient removal and reduce land requirements include introduction of floating elements to improve hydraulic characteristics and attachment of algae and bacteria such as duckweed and water hyacinths systems (Bigambo, 2003; Senzia, 2003; Bal Krishna and Polprasert, 2008).

Nitrogen is becoming increasingly important in wastewater management because nitrogen can have many effects on the environment (Halling-Sørensen and Jørgensen, 1993). Excessive discharge of nitrogen in aquatic ecosystem can contribute to degradation of water quality (Showers et al., 2006), can cause adverse ecological impacts and can affect public health (Sedlak, 1991; http://ammoniabmp.colostate.edu, 2013). For instance, ammonia is extremely toxic to fish and many other aquatic organisms such as algae and it is also an oxygen consuming compound, which can deplete the dissolved oxygen in water (Konig et al., 1987). The depletion of dissolved oxygen in water causes ecological imbalance since maintenance of a high oxygen concentration is crucial for survival of the higher life forms in aquatic ecosystem. Excessive concentration of nitrate and ammonia can cause changes in ecosystem, which may disrupt natural balance of the system. As a result fragile plants and animal species can be replaced by nitrogen-responsive species, which may lead to disruption or even extinction of the ecosystem (http://ammoniabmp.colostate.edu, 2013). Orji et al. (2011) observed that excessive concentration of nitrogen from abattoir wastes was capable of causing shifts in microbial community structure and altering aquatic nitrogen cycle.

Another ecological impact is eutrophication caused by the excessive growth of bacteria and algae due to the increase of the amount of nitrogen discharged into water. Eutrophication contributes to the reduction of the oxygen level in water. Nitrite is a potential public health hazard in water consumed by infants (Sedlak, 1991). In the body, nitrite can oxidize the iron (II) and cause methamoglobinaemia, which binds oxygen less effectively than normal haemoglobin. The resulting decrease in oxygen levels in young children leads to diarrhea, vomiting, and in extreme cases even death (Kelter et al., 1997). The problems that all these incidents have posed are a clear indication that nitrogen removal in wastewater is important before effluent is finally discharged into receiving water body.

In an attempt to understand nitrogen transformation mechanisms researches have been carried out worldwide and models developed in various environments. These environments include activated sludge treatment plants (Charley et al., 1980), algae-based waste stabilization ponds (Ferrara and Hermann, 1980; Senzia et al., 2002; Senzia et al., 2003), attached growth systems (Shin and Polprasert, 1988; Mutamba, 2002, Mkama, 2005), river deltas and estuarines (Di Toro et al., 1971; Najarin, 1984) constructed wetlands (Senzia et al., 2004; Mayo and Bigambo, 2005), natural wetlands (Muraza, 2013), duckweed systems (Bal Krishna and Polpersert, 2008), water hyacinths ponds (Dallah, 2001; Mayo and Bigambo, 2005) and high rate ponds (Mayo and Mutamba, 2005). Some research studies have established the performance of individual waste stabilization ponds (Senzia, 1999; Mayo and Mutamba, 2005), but no attempt has been made to establish the overall performance of the whole system. Therefore, to achieve the performance of the entire system mass balance became a prominent tool to tackle the problem. The objective of this research was to identify major nitrogen transformation and removal mechanisms in different types of ponds.

\section{METHODOLOGY}

\section{Description of the study area}

The University of Dar es Salaam (UDSM) pond system is located at latitude $6^{\circ} 48^{\prime} \mathrm{S}$ and longitude $39^{\circ} 13^{\prime} \mathrm{E}$. It has one primary facultative pond $(F 1)$, two lines each with two secondary facultative ponds (F2, F3, $\mathrm{F}^{*}$ and $\left.\mathrm{F}^{*}\right)$ and one maturation pond $\left(\mathrm{M}\right.$ and $\left.\mathrm{M}^{*}\right)$. They receive wastewater flow of about $840 \mathrm{~m}^{3} /$ day mainly of domestic nature and also some chemical wastes flows from laboratories and workshops. Figure 1 shows a schematic layout of the pond system at the University of Dar es Salaam. Operational characteristics and wastewater flows are shown in Table 1.

Samples were collected both in the influent and effluent of each pond for examination of organic-nitrogen, ammonia-nitrogen and nitrate-nitrogen in water quality laboratory at the University of Dar es Salaam in accordance with the Standard methods (1996). Wastewater flow rate, temperature, $\mathrm{pH}$, dissolved oxygen (DO) were measured in situ.

\section{Model development}

Nitrogen transformation in waste stabilization ponds was developed using conceptual model shown in Figure 2. A simplified and appropriate nitrogen cycle was developed paying particular attention to mineralization, nitrification/denitrification, uptake by micro-organisms (algae and bacteria), permanent sedimentation (net loss) and ammonia volatilization, as dominant nitrogen pathways.

For mathematical simplicity, either a first order plug flow regime (Reed, 1985; Mayo, 1995; Thirumurthi, 1969) or completely mixed flow (Ferrara and Hermann, 1980; Shin and Polprasert, 1988; Fritz et al., 1979; Somiya and Fujii, 1984) models were adopted. Assuming completely mixed flow regime, a complete materials 


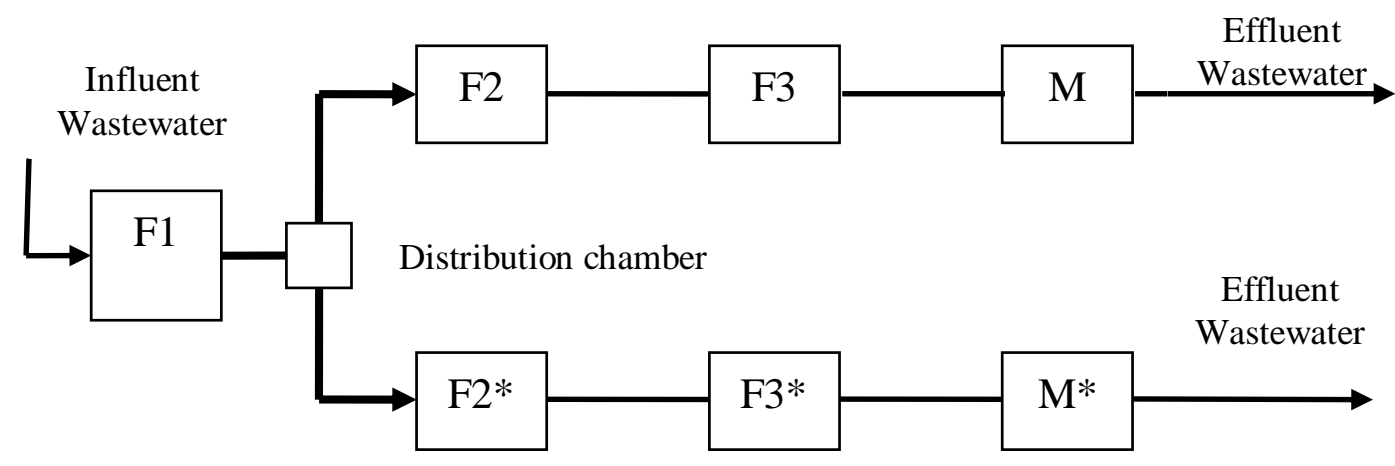

Figure 1. The layout of waste stabilization pond system at the UDSM.

Table 1. Hydraulic elements and wastewater flows (Senzia, 1999).

\begin{tabular}{lcccc}
\hline Pond type & F1 & F2 & F3 & M \\
\hline Retention time (days) & 11.5 & 12.2 & 12.5 & 7.6 \\
Flow rate $\left(\mathrm{m}^{3} / \mathrm{d}\right)^{+}$ & 528.23 & 252.41 & 245.61 & 241.41 \\
Volume $\left(\mathrm{m}^{3}\right)$ & $6080^{*}$ & 3070 & 3070 & 1824 \\
Water depth $(\mathrm{m})$ & $1.33^{*}$ & 1.51 & 1.51 & 1.22 \\
Mid pond surface area $\left(\mathrm{m}^{2}\right)$ & 4065 & 2100 & 2100 & 1425 \\
\hline
\end{tabular}

+ These are mean values; * these are estimated values, which took into account sludge accumulation $\left(910 \mathrm{~m}^{3}\right)$ since the pond was desludged in 1986. In 1986, the depth and volume of the pond were $1.82 \mathrm{~m}$ and $6990 \mathrm{~m}^{3}$, respectively.

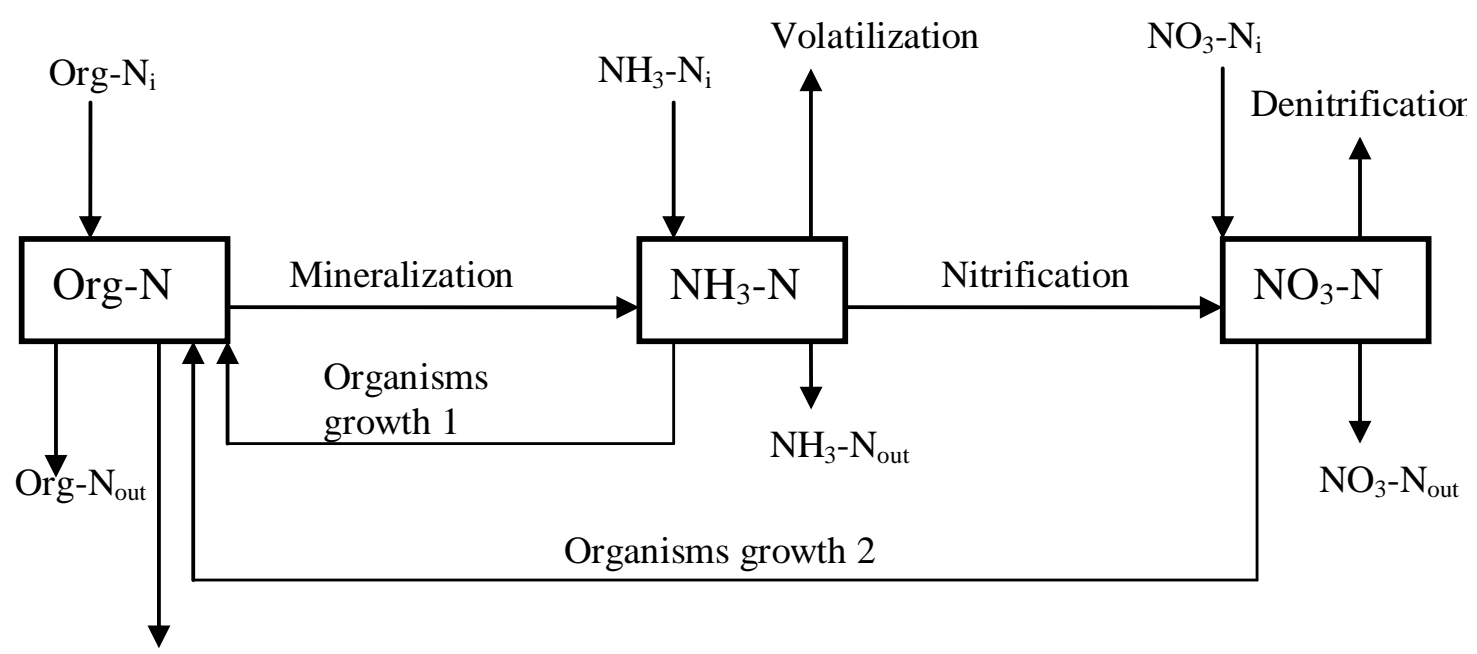

Net loss to the sediments

Figure 2. Nitrogen transformation and removal in WSP. 
Where, $C=$ Effluent concentration of the substance in $\mathrm{mg} / \mathrm{l}$ (e.g. $\mathrm{NH}_{3}-\mathrm{N}$ from the pond); $V=$ Reactor volume in $\mathrm{m}^{3} ; r_{c}=$ Volumetric reaction rate of the state variable $(\mathrm{mg} / \mathrm{l} . \mathrm{d}) ; C_{i}=$ Influent concentration of the substance in $\mathrm{mg} / \mathrm{l}$ (e.g. $\mathrm{NH}_{3}-\mathrm{N}$ from raw wastewater); $m=$ Number of reactions that involve the substance; $V(d C / d t)=$ Volumetric rate of change of substance in the reactor $(\mathrm{mg} / \mathrm{l} . \mathrm{d}) ; Q_{i}=$ Influent flow rate in $\mathrm{m}^{3} /$ day; $Q_{0}=$ Effluent flow rate in $\mathrm{m}^{3} /$ day.

With reference to the conceptual model in Figure 2, the mass balance equations for organic nitrogen (Org- $\mathrm{N})$, ammonia nitrogen $\left(\mathrm{NH}_{3}-\mathrm{N}\right)$ and nitrate nitrogen $\left(\mathrm{NO}_{3}-\mathrm{N}\right)$ was given by Equations 2, 3 and 4 , respectively.

$$
\begin{aligned}
& \frac{d(O r g-N)}{d t}=\frac{Q_{i}}{V}(\text { Org }-N)_{i}-\frac{Q_{e}}{V}(O r g-N)-r_{m}-r_{s}+r_{1}+r_{2} \\
& \frac{d\left(N H_{3}-N\right)}{d t}=\frac{Q_{i}}{V}\left(N H_{3}-N\right)_{i}-\frac{Q_{e}}{V}\left(N H_{3}-N\right)-r_{1}+r_{m}-r_{v}-r_{n} \\
& \frac{d\left(N O_{3}-N\right)}{d t}=\frac{Q_{i}}{V}\left(N O_{3}-N\right)_{i}-\frac{Q_{e}}{V}\left(N O_{3}-N\right)+r_{n}-r_{2}-r_{d}
\end{aligned}
$$

Where, $r_{n}=$ Nitrification rate, $(\mathrm{mg} / \mathrm{l} . \mathrm{d}) ; r_{d}=$ Denitrification rate, (mg/l.d); $r_{m}=$ Mineralization rate, $(\mathrm{mg} / \mathrm{l} . \mathrm{d}) ; r_{s}=$ Net loss of organic nitrogen, $(\mathrm{mg} / \mathrm{l} . \mathrm{d}) ; r_{v}=$ Volatilization rate, $(\mathrm{mg} / \mathrm{l} . \mathrm{d}) ; r_{1}=$ Uptake rate of $\mathrm{NH}_{3}-\mathrm{N}$ by micro-organisms, (mg /l.d); $r_{2}=$ Uptake rate of $\mathrm{NO}_{3}-\mathrm{N}$ by micro-organisms (mg/l.d).

Mineralization of organic nitrogen was modeled using first order kinetics with respect to organic nitrogen concentrations (Di Toro et al., 1971). Mineralization process depends on temperature and concentration of organic nitrogen and may be computed from Equation 5.

$$
r_{m}=0.002 T \times(O r g-N)
$$

The rate of nitrification, $r_{n}$ which is governed by the growth of chemoautotrophic nitrifying bacteria, depends on the $\mathrm{pH}$, temperature and concentration of ammonia and dissolved oxygen (Equation 6).

$$
r_{n}=\frac{U_{n}}{Y_{n}}\left(\frac{\mathrm{NH}_{4}}{\mathrm{~K} 1+\mathrm{NH}_{4}-\mathrm{N}}\right) \times\left(\frac{\mathrm{DO}}{\mathrm{K} 2+\mathrm{DO}}\right) \times C_{T} \times C_{p H}
$$

In which $C_{P H}$ is the nitrosomonas growth limiting factor for $\mathrm{pH}$. Downing (1966) reported that for $\mathrm{pH} \geq 7.2$ no significant inhibition occurs and therefore $C_{P H}=1.0$. When $\mathrm{pH}$ falls below 7.2 , the existence of free ammonia inhibits growth of nitrifying bacteria. Therefore, the nitrification rate is corrected in accordance with Equation 7.

$$
C_{p H}=1-0.833(7.2-p H)
$$

The term $K_{1}$, which is half saturation constant for nitrosomonas is temperature-dependent (Downing, 1966) in accordance with Equation 8.

$$
K_{1}=10^{(0.051(T-1.58))}
$$

Nitrification is also temperature-dependent. Over the range of 5 to $30^{\circ} \mathrm{C}$, the exponential model shown by Equation 9 describes the temperature correction factor.

$$
C_{T}=e^{\alpha\left(T-T_{o}\right)}
$$

Where, $T_{0}$ is the reference temperature and $\alpha$ is an empirical constant. The values of $T_{0}$ and $\alpha$ were $15^{\circ} \mathrm{C}$ and $0.098 /{ }^{\circ} \mathrm{C}$, respectively.

The maximum growth rate and yield coefficient of nitrosomonas were assumed to be 0.008 day $^{-1}$ and 0.13 , respectively (Charley et al., 1980). The oxygen nitrosomonas half saturation $K_{2}$ was assumed to be $1.3 \mathrm{mg} / \mathrm{l}$ in accordance with Downing (1966).

Denitrification rate, $r_{d}$ in ponds is a function of temperature and $\mathrm{NO}_{3}-\mathrm{N}$ concentration in wastewater it is given by Equation 10 (Fritz et al., 1979).

$$
r_{d}=R 2_{20} \theta^{(T-20)} N O_{3}-N
$$

The Arrhenius constant $\theta$ varies from 1.02 to 1.09 and denitrification constant $R 2_{20}$ may vary from 0 to 1 (Bacca and Arnett, 1976).

The rate of $\mathrm{NH}_{3}-\mathrm{N}$ volatilization depends on the concentration of ammonia gas in the liquid, temperature, depth of the pond and $\mathrm{pH}$ of the water. $\mathrm{NH}_{3}-\mathrm{N}$ in water exists as dissolved ammonia gas $\left(\mathrm{NH}_{3}-\right.$ $\mathrm{N}(\mathrm{g})$ or ammonium ions $\left(\mathrm{NH}_{4}^{+}\right)$.

The concentration of $\mathrm{NH}_{3}-\mathrm{N}(\mathrm{g})$ is $\mathrm{pH}$ and temperature-dependent according to the Equation 11.

$$
N H_{3}-N(g)_{c o n c}=\frac{N H_{3}-N}{1+10^{(10.5-0.032 T-p H)}}
$$

The rate of ammonia volatilization is influenced by mass transfer coefficient $K I$ as shown by Equation 12 (Stratton, 1969):

$$
K I=0.0566 \times \operatorname{Exp}(0.13(T-20))
$$

Where, $T=$ water temperature in ${ }^{\circ} \mathrm{C}$

The rate of $\mathrm{NH}_{3}-\mathrm{N}$ volatilization is given by Equation 13 .

$$
r_{v}=0.0566 \times \operatorname{Exp}(0.13(T-20))\left[\frac{N H_{3}-N}{10^{(10.05-0.032 T-p H)}}\right]
$$

The net loss of nitrogen to the sediments depends on the concentration of organic nitrogen according to Equation 14.

Net loss, $r_{s}=R 1(O r g-N)$

Non-biodegradable organic nitrogen was assumed to settle in the sediments and thus contributed to the permanent removal of nitrogen. The coefficient $R 1$ was obtained from the model calibration.

The microbial uptake was modeled using Monod kinetics. The preference factors $\mathrm{P} 1$ and $\mathrm{P} 2$ for $\mathrm{NH}_{3}-\mathrm{N}$ and $\mathrm{NO}_{3}-\mathrm{N}$, respectively were introduced since $\mathrm{NH}_{3}-\mathrm{N}$ must be depleted before nitrate can be utilized for cell synthesis (Fritz et al., 1979; Ferrara and Avci, 1982; EPA, 1985). It was assumed that each time an organism produces a new biomass, a certain amount of that material 
Table 2. Optimized parameters for wastewater stabilization pond.

\begin{tabular}{|c|c|c|c|c|c|c|}
\hline \multirow{2}{*}{ Parameter } & \multirow{2}{*}{ Range } & \multirow{2}{*}{ Reference } & \multicolumn{4}{|c|}{ Optimum } \\
\hline & & & F1 & F2 & F3 & $\mathbf{M}$ \\
\hline Settling rate & $0.001-0.1 /$ day & Jørgensen et al. (1991) & 0.024 & 0.001 & 0.001 & 0.001 \\
\hline Nitrosomonas yield coefficient (Yn) & $\begin{array}{l}0.03-0.13 \mathrm{mg} \\
\mathrm{VSS} / \mathrm{mgN}\end{array}$ & Charle et al. (1980) & 0.13 & 0.10 & 0.13 & 0.10 \\
\hline Nitrosomonas maximum growth rate (Un) & $0.0-0.008$ & Fritz et al. (1979) & 0.008 & 0.008 & 0.008 & 0.008 \\
\hline Arrhenius constant $\theta$ & $1.02-1.08$ & Najarian (1984) & 1.02 & 1.02 & 1.08 & 1.08 \\
\hline Nitrosomonas half saturation constant & $0.3-1.3 \mathrm{mg} / \mathrm{l}$ & Fritz et al. (1979) & 1.3 & 0.13 & 1.3 & 0.3 \\
\hline Denitrification rate at $20^{\circ} \mathrm{C}\left(\mathrm{DR} \_20\right)$ & $0.0-1.0 /$ day & Bacca and Arnett (1976) & 0.07 & 0.2 & 0.06 & 0.07 \\
\hline $\begin{array}{l}\text { Microorganism maximum growth rate at } 20^{\circ} \mathrm{C} \\
\left(\mu_{\max , 20)}\right.\end{array}$ & $0.18-0.77$ & $\begin{array}{l}\text { Ferrara and Hermann } \\
(1980)\end{array}$ & 0.18 & 0.18 & 0.45 & 0.77 \\
\hline
\end{tabular}

becomes locked into a non-biodegradable form that will settle and remain in the pond sediments. $\mathrm{NH}_{3}-\mathrm{N}$ and $\mathrm{NO}_{3}-\mathrm{N}$ is converted to biomass in accordance with Equations 15 and 16, respectively.

Microorganisms growth 1

$r_{1}=\mu_{\max 20} \theta^{(T-20)}\left[\frac{N H_{3}-N}{K_{3}+N H_{3}-N}\right](O r g-N) \times P_{1}$

Microorganisms growth 2

$r_{2}=\mu_{\max 20} \theta^{(T-20)}\left[\frac{N O_{3}-N}{K_{4}+N O_{3}-N}\right](O r g-N) \times P_{2}$

The modeling process was carried out by using Stella II software, which was used to determine the best values of unknown coefficients, used in the model. This software has four main components that include forcing functions, state variables, mathematical equation and parameters. The model was validated using different set of data collected at the University of Dar es Salaam waste stabilization ponds (WSP).

Mass balance was done only to the ponds in route F1, F2, F3 and $M$. In each pond, data were processed using fourth-order Runge-Kutta approximation incorporated in Stella II software. Each pond was optimized differently. The effluent concentrations of Org$\mathrm{N}, \mathrm{NH}_{3}-\mathrm{N}$ and $\mathrm{NO}_{3}-\mathrm{N}$ was taken to be the inflow of another pond, that is, effluent concentration of pond $F 1$ was the influent concentration of pond F2, effluent concentration of pond F2 was the influent concentration of pond $\mathrm{F} 3$, and effluent concentration of pond F3 was the influent concentration of pond $M$. The aim of considering concentration was to incorporate the loss of flow from one pond to another.

\section{RESULTS AND DISCUSSION}

\section{Model simulation}

Influent wastewater characteristics, environmental conditions and kinetic coefficients were used for simulation. The model simulation was done using data collected for 50 days. The simulated values were then compared with the observed values. A number of itera- tions were done to determine the optimum parameters, which would reasonably simulate the wastewater quality response of the ponds. The optimized parameter values determined from the model simulations on University of Dar es Salaam wastewater stabilization pond system are listed in Table 2.

To demonstrate successful simulation, the observed and the predicted values for organic-nitrogen and ammonia-nitrogen for primary facultative pond F1 are shown in Figures 3 and 4, respectively. The predicted values for the simulated organic nitrogen, ammonia nitrogen and nitrate nitrogen agree well with the observed values as shown by correlation coefficient ranging from 0.59 to 0.77 . Therefore, the agreement between the model output and the observed effluent concentration is reasonably good given that data was collected in the field where environmental, chemical and physical factors were not controlled.

\section{Nitrogen mass balance}

Figure 5 shows daily average nitrogen mass balance in waste stabilization ponds system at the University of Dar es Salaam.

The major nitrogen transformation mechanisms in the primary pond were mineralization and uptake of ammonia, which were accounting for 39.1 and $35.4 \%$ of the total nitrogen transformed, respectively (Table 3 ). High rate of mineralization in the primary pond was caused by decomposition of large mass of organic material received in this pond particularly in the benthic layer.

This also explains the increase in concentration of ammonia in pond F1. It is worth mentioning that net sedimentation loss of nitrogen in the primary pond of $1413 \mathrm{~g} /$ day was not matched by any of the subsequent pond. In secondary facultative pond F3 and maturation pond uptake of ammonia was slightly more dominant than mineralization owing to reduced mass of organic nitrogen. Uptake of ammonia was 33.9 and $35.9 \%$ of the 


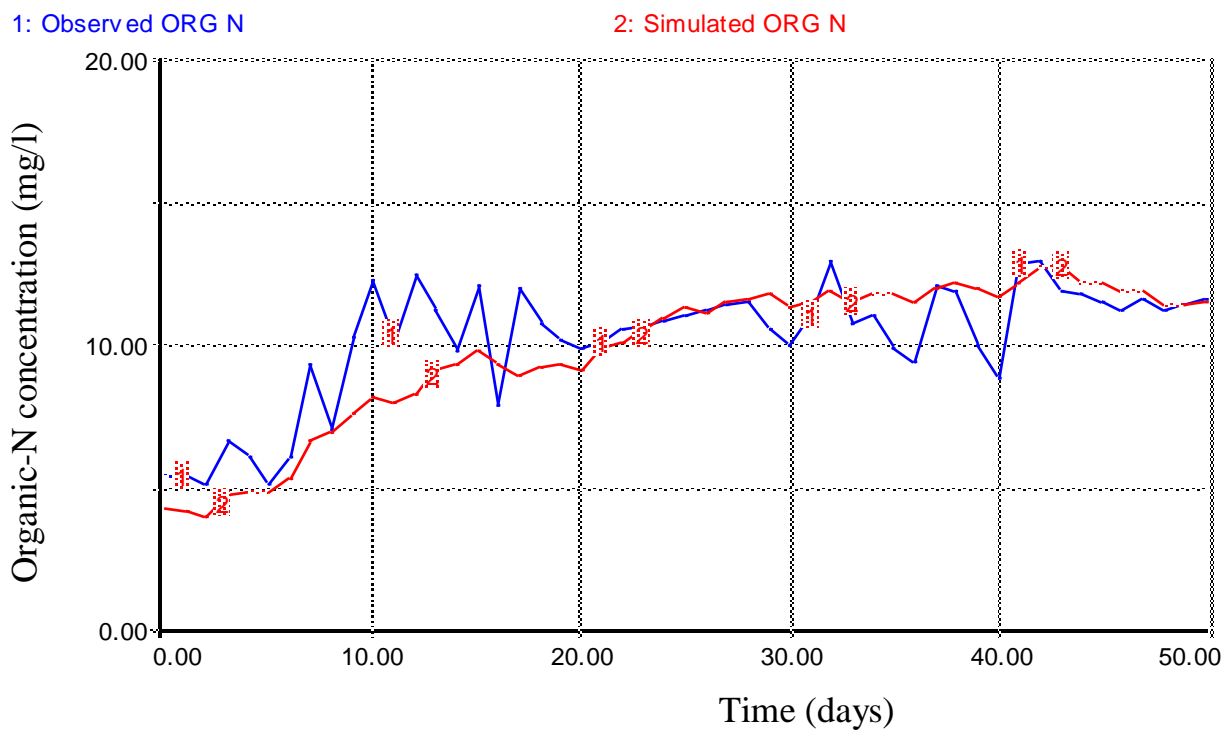

Figure 3. Organic nitrogen concentration variation with time in pond F1.

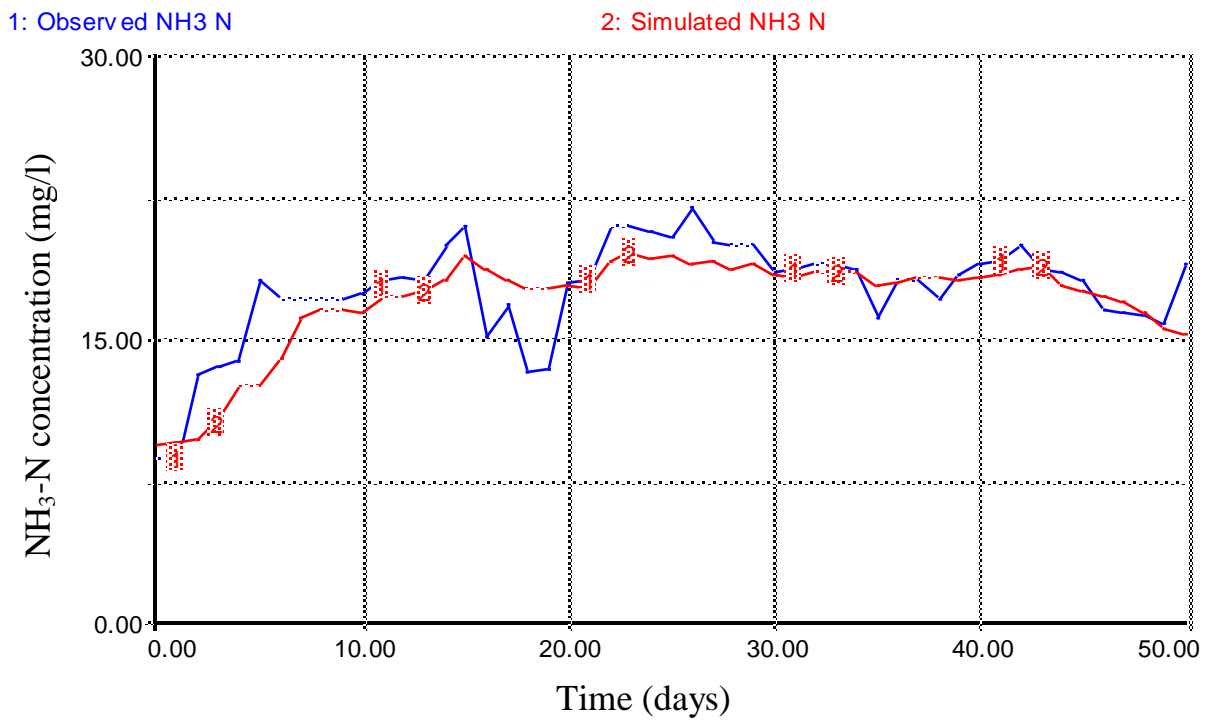

Figure 4. Ammonia nitrogen concentration variation with time in pond F1.

total nitrogen transformed in the secondary facultative pond $\mathrm{F} 3$ and maturation pond, respectively. These transformation rates were higher than 31.7 and $34.7 \%$ for mineralization in the same ponds, respectively.

However, in secondary facultative pond F2, nitrification and denitrification were the dominant nitrogen transformation mechanisms and were responsible for 31.3 and $26.2 \%$ of total nitrogen transformed. Increased rate of nitrification was a result of increased concentration of ammonia concentration following mineralization of organic nitrogen in primary pond F1 and high concentration of oxygen in secondary pond F2. Low nitrification rate in pond $\mathrm{F} 1$ was caused by the low concentration of dissolved oxygen.

\section{Permanent nitrogen removal}

It is worth mentioning that wastewater received in the primary pond $\mathrm{F} 1$ is divided in two series of three ponds each (Figure 1). Flow measurements indicate that pond $\mathrm{F} 2$ received $55.5 \%$ of the total flow and therefore the same proportion of nitrogen mass was assumed to flow in this pond. It may therefore be assumed that the mass load of nitrogen in the influent of primary pond $\mathrm{F} 1$ 


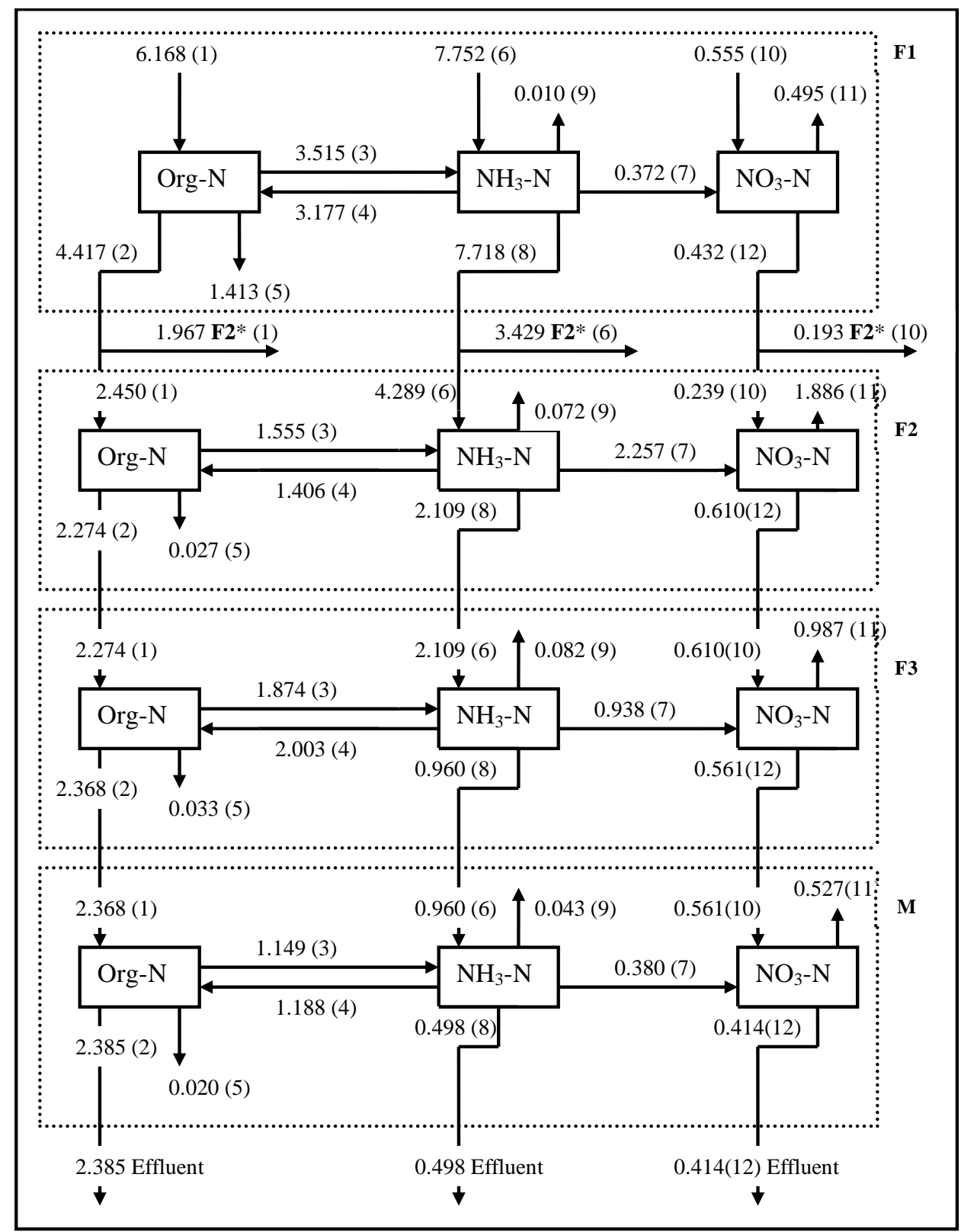

Figure 5. Nitrogen mass balance in waste stabilization ponds system. Numbers in parenthesis represents: (1) Organic-nitrogen flowing to the pond, (2) organic-nitrogen flowing out of the pond, (3) mineralization of organic-nitrogen to $\mathrm{NH}_{3}-\mathrm{N}$, (4) $\mathrm{NH}_{3}-\mathrm{N}$ uptake by micro-organisms for their growth, (5) organic-nitrogen lost to the sediment by settling, (6) $\mathrm{NH}_{3}-\mathrm{N}$ flowing to the pond, (7) nitrification of $\mathrm{NH}_{3}-\mathrm{N}$ to $\mathrm{NO}_{3}-\mathrm{N}$, (8) $\mathrm{NH}_{3}-\mathrm{N}$ flowing out of the pond, (9) volatilization of $\mathrm{NH}_{3}-\mathrm{N}$ to $\mathrm{NH}_{3}-\mathrm{N}(\mathrm{g})$, (10) $\mathrm{NO}_{3}-\mathrm{N}$ flowing to the pond, (11) denitrification of $\mathrm{NO}_{3}-\mathrm{N}$ to $\mathrm{N}_{2}(\mathrm{~g})$ and (12) $\mathrm{NO}_{3}-\mathrm{N}$ flowing out of the pond.

Table 3. Nitrogen removal mechanisms (kg/day).

\begin{tabular}{lccc}
\hline Pond & Denitrification & Sedimentation & Volatilization \\
\hline Primary facultative pond F1 & 0.274 & 0.784 & 0.006 \\
Secondary facultative pond F2 & 1.886 & 0.027 & 0.072 \\
Secondary facultative pond F3 & 0.987 & 0.033 & 0.082 \\
Maturation pond M & 0.527 & 0.020 & 0.043 \\
Total & 3.674 & 0.864 & 0.203 \\
\hline
\end{tabular}


contributing to series F2, F3 and M were $3.421 \mathrm{~kg} /$ day of organic nitrogen, $4.308 \mathrm{~kg} /$ day of ammonia-nitrogen and $0.307 \mathrm{~kg} /$ day of nitrate-nitrogen. With the same reasoning, the proportion of net sedimentation, ammonia volatilization and denitrification will be $0.784,0.006$ and $0.274 \mathrm{~kg} /$ day, respectively.

In accordance with mass balance presented in Figure 5 as summarized in Table 3, the pond system was able to remove $4741 \mathrm{~g} /$ day of nitrogen in from inflow load of 8036 $\mathrm{g} /$ day, which is equivalent to nitrogen removal efficiency of $59 \%$. This removal efficiency is within typical range of total nitrogen removal efficiency of 20 to $80 \%$ in pond systems reported elsewhere (Rockne and Brezonik, 2006; Isosaari et al., 2010). However, it is worth to note that a wide range of removal efficiency is a result of multifactors responsible for removal of nitrogen in pond systems. These factors include hydraulic retention time, water depth (Alahmady et al., 2013), high pH levels which is responsible for removal of unionized ammonia (Rockne and Brezonik, 2006), temperature and dissolved oxygen (Fritz et al., 1979; Faleschini et al., 2012).

The overall dominant removal mechanism is denitrifycation, which was responsible for $77.5 \%$ of the removed nitrogen followed by net loss of nitrogen to sediments $(18.2 \%)$ and volatilization (4.3\%). Volatilization of unionized ammonia was insignificant in this study, although in few studies in cold climates indicate that this mechanism was a dominant nitrogen removal mechanism during late spring when $\mathrm{pH}$ was above 8 and ammonia levels were still high (Rockne and Brezonik, 2006). However, other studies have reported that nitrificationdenitrification is the dominant nitrogen removal mechanism (Faleschini et al., 2012; Senzia, 2003; Mkama, 2005, Muraza, 2013), which is in agreement with the results of this study. However, net loss of nitrogen to sediments was the dominant removal of nitrogen in primary facultative pond $\mathrm{F} 1$ accounting for $73.6 \%$ of the total nitrogen removed in that pond. It is worth mentioning that the primary pond receives large mass of suspended solids from the University community, which settled down and subsequently decomposed in the bottom benthic layer. Senzia (1999) and later Mkama (2005) observed the dominance of sedimentation in nitrogen removal in primary pond systems. In the subsequent secondary facultative ponds and maturation ponds, denitrification was the dominant nitrogen removal mechanism owing to increased nitrate content in these ponds. The dominance of denitrification as the dominant mechanism for nitrogen removal in maturation ponds has also been reported by Mtweve (1999).

\section{Sedimentation}

Owing to large quantity of particulate organic matter in the primary facultative pond $\mathrm{F} 1$, large quantity of organic matter was settled and removed in the primary pond as compared to other ponds. As a result $1.413 \mathrm{~kg} /$ day of organic-nitrogen was removed in pond $\mathrm{F} 1$ but only 0.027 , 0.033 and $0.020 \mathrm{~kg} /$ day were removed in ponds F2, F3 and $\mathrm{M}$, respectively because of decreased concentration of organic-nitrogen.

\section{Volatilization}

Volatilization was the weakest transformation route of nitrogen in the pond system. Facultative pond F3 had the best volatilization rate of $0.082 \mathrm{~kg} /$ day of ammonianitrogen. However, only 0.072 and $0.043 \mathrm{~kg} /$ day of ammonia-nitrogen were removed in secondary facultative pond $\mathrm{F} 2$ and maturation pond $\mathrm{M}$ while primary facultative pond $\mathrm{F} 1$ removed the lowest rate of $0.010 \mathrm{~kg} /$ day of ammonia-nitrogen. Volatilization rate was higher in pond F3 as compared to other ponds because of increased pH range of 8.01 - 10.03. Ammonia in water exists in equilibrium between the ionized $\left(\mathrm{NH}_{4}{ }^{+}\right)$and free $\left(\mathrm{NH}_{3}\right)$ forms. The free $\mathrm{NH}_{3}$ form is volatile and may be lost to the atmosphere as a gas in a physical process. The equilibrium between the two forms depends on temperature and $\mathrm{pH}$. At $\mathrm{pH}$ above 6.6, $\mathrm{NH}_{4}^{+}$starts to convert to the volatile $\mathrm{NH}_{3}$ form; at $\mathrm{pH} 9.2$ the two forms are equal in concentration, and at $\mathrm{pH} 12$ all the ammonia is in $\mathrm{NH}_{3}$ form (Reed, 1985). Consequently, loss by volatilization is more likely at higher $\mathrm{pH}$. It is worth mentioning that volatilization rate was not a major removal factor in ponds at the University of Dar es Salaam because the range of 6.82 to 10.03 did not allow sufficient volatilization.

\section{Denitrification}

Denitrification rate of $1.886 \mathrm{~kg} /$ day of nitrate-nitrogen in the secondary facultative pond, F2 was the highest as compared to $0.987,0.527$ and $0.495 \mathrm{~kg} /$ day of nitratenitrogen in ponds F3, M and F1, respectively. Denitrification is normally limited to the amount of nitrate produced and dissolved oxygen present in wastewater. In a case like this denitrification should take place especially in the sediment zone, anaerobic layer or during the night when dissolved oxygen has been consumed for respiration by algae and bacteria (Ferrara and Avci, 1982).

\section{Mineralization}

Mineralization rate of organic-nitrogen was $3.515 \mathrm{~kg} / \mathrm{day}$ in the primary facultative pond $\mathrm{F} 1$, which is higher than $1.555,1.874$ and $1.149 \mathrm{~kg} /$ day observed in ponds F2, F3 and $M$, respectively. High mineralization rate in pond $F 1$ was due to decomposition of organic nitrogen introduced via wastewater influent which is readily converted to 
ammonia. This explains the increase of ammonia concentration in the primary facultative pond $\mathrm{F} 1$.

\section{Nitrification}

Nitrification rate in the secondary facultative pond F2 was the highest transformation route as compared to the other ponds, which transformed $2.257 \mathrm{~kg} / \mathrm{day}$ of ammonianitrogen in the pond. This pond had a favorable nitrification rate because of high concentration of dissolved oxygen, optimum temperature for the growth of nitrifying bacteria, which was ranging between 27.0 and $32.2^{\circ} \mathrm{C}$ and favorable $\mathrm{pH}$ value ranging between 7.0 and 7.95, which is optimum for nitrosomonas bacteria. Nitrification rate decreased to 0.938 and $0.380 \mathrm{~kg} /$ day in secondary facultative pond $\mathrm{F} 3$ and maturation pond $\mathrm{M}$, respectively because of decrease in concentration of ammonia and increase of $\mathrm{pH}$, although dissolved oxygen remained high. Low nitrification rate in pond $\mathrm{F} 1$ was caused by low concentration of dissolved oxygen and inadequate time for nitrosomonas and nitrobacter to act upon ammonia-nitrogen.

\section{Ammonia uptake}

The uptake of ammonia by microorganisms was highest in the primary facultative pond $\mathrm{F} 1$ and $3.177 \mathrm{~kg} /$ day was consumed. This was because of preference for ammonia as a source of nitrogen for cellular growth by microorganisms (Konig et al., 1987) and high concentration of ammonia in the pond. Secondary facultative ponds (F2 and $\mathrm{F} 3$ ) and maturation pond M transformed through this route: 1.406, 2.003 and 1.188 $\mathrm{kg} /$ day of ammonia-nitrogen, respectively. Algal nitrogen uptake is known to be a significant contributor to nitrogen removal in waste stabilization ponds (Faleschini et al., 2012; Senzia et al., 2002). However, in the absence of algal removal systems such as sub-surface flow wetland systems and gravel bed filters (Senzia et al., 2004; Mayo and Mutamba, 2005), nitrogen stored in algal biomass will be discharged back to the environment.

\section{Conclusions}

Based on the results presented, it is concluded that:

1. In a primary facultative pond, mineralization and ammonia uptake were the major forms of transformation, which was responsible for 39.1 and $35.4 \%$, respectively, of the total nitrogen transformed. However, in secondary facultative pond (F2), contribution of nitrification and denitrification were the dominant transformation mechanisms accounting for 31.3 and $26.2 \%$ of the total nitrogen transformed. In secondary facultative pond F3 and maturation pond uptake of ammonia became the major trans- transformation route responsible for 33.9 and $35.9 \%$ of the total nitrogen transformed. In these ponds, mineralization was the second major transformation route.

2. The major permanent nitrogen removal mechanism in primary facultative pond $\mathrm{F} 1$ was sedimentation, which was responsible for $73.7 \%$ of total nitrogen removal. Denitrification was the major removal mechanism in secondary facultative ponds (F2 and F3) and maturation pond (M), which accounted for 95.0, 89.4 and $89.1 \%$, respectively of total nitrogen removed in the ponds.

3 . The effluent in maturation pond, $M$ contains high concentration of organic nitrogen associated with particulate matter such as algae. It is recommended to remove suspended solids in the final effluent using gravel bed media or subsurface flow constructed wetlands.

\section{REFERENCES}

Alahmady K, Stevens K, Atkinson S (2013). Effects of hydraulic detention time, water depth and duration of operation on nitrogen and phosphorus removal in a flow-through duckweed bioremediation system. J. Environ. Eng. Div. Am. Soc. Civ. Eng. 139(2): 160-166.

Al-Sa'ed R (2007). Sustainability of natural and mechanized aerated ponds for domestic and municipal wastewater in Palestine. Water Int. 32(2):310-324

Al-Sa'ed R, Abu-Madi M, Zimmo O (2011). Novel design concept for facultative ponds using rock filters to reclaim the effluent". J. Environ. Eng. Div. Am. Soc. Civ. Eng. 137(4):284-290.

Bacca RG, Arnett RC (1976). A limnological model for eutrophic Lakes and impoundment, Battele, Inc, Pacific Northwest Laboratories, Richland.

Bal Krishna KC, Polprasert C (2008). An integrated kinetic model for organic and nutrient removal by duckweed-based wastewater treatment (DUBWAT) system. Ecol. Eng. 34(3): 243-250.

Barrie A (2002). Modelling COD removal in water hyacinth constructed wetland, MSc Dissertation, Department of Water Resources Engineering, University of Dar es Salaam, Tanzania.

Bigambo T (2003). The effects of Biofilm Activities on Nitrogen Transformation in Horizontal Subsurface Flow Constructed Wetlands MSc Dissertation, University of Dar es Salaam, Tanzania.

Charley RC, Hoper DG, McLee AG (1980). Nitrification kinetics in activated sludge at various temperatures and dissolved oxygen concentrations. Water Res. 14:1387-1396.

Dallah Ali (2001). Nitrogen Removal in water Hyacinth Constructed Wetland, MSc Dissertation University of Dar es Salaam, Tanzania.

Di Toro DM, O'Connor DJ, Thomann RV (1971). A dynamic model of the phytoplankton population in Sacramento-San Joaquin delta, In non equilibrium systems in natural water chemistry, Adv. Chem. Ser. 106. American Chemical Society, Washington DC. pp. 131-180.

Downing AL (1966). Population Dynamics in Biological Systems, Proc. $3^{\text {rd }}$ International Wat. Pol., Res., WPCF, Munich, Germany, Series 2, 117-137.

Environmental Protection Agency (EPA) (1985). Rates, constants, and kinetics formulations in surface water quality modeling, Environmental research laboratory, Athens, Georgia, U.S.A.

Faleschini M, Esteves JL, Camargo Valero MA (2012). The effects of hydraulic and organic loadings on the performance of a full-scale facultative pond in a temperate climate region (Argentine Patagonia). Water Air Soil Pollut. 223(5):2483-2493.

Ferrara RA, Avci CM (1982). Nitrogen Dynamics in Waste Stabilization Ponds. J. Water Pollut. Cont. Fed. 54(4): 361 - 369.

Ferrara RA, Hermann DPF (1980). Dynamic Nutrient Cycle Model for Waste Stabilization Ponds. J. Environ. Eng. Div. Am. Soc. Civ. Eng. 106(1): 37-55.

Fritz JF, Middleton AC, Meredith DD (1979). Dynamic Process Modelling of Wastewater Stabilisation Ponds. J. Water Pollut. Cont. Fed. 51(11):2724-2743. 
Halling-Sørensen B, Jørgensen SE (1993). The removal of nitrogen compounds from wastewater, Elsevier, London.

Hanai E (2006). Nitrogen transformation in a coupled High rate- Water hyancinths ponds. Masters of Integrated Environmental Management dissertation, Department of Chemical and Process Engineering, University of Dar es Salaam, Tanzania.

Isosaari P, Hermanowicz SW, Rubin Y (2010). Sustainable natural systems for treatment and disposal of food processing wastewater. Crit. Rev. Environ. Sci. Technol. 40:662-694.

Jørgensen SE, Nielsen SN, Jørgensen LA (1991). Handbook of ecological parameters and ecotoxicology, Elsevier, Amsterdam.

Kalibbala M (2001). Influence of Water hyacinth on the presence of pathogens in wastewater ponds, MSc (Water Resources Eng) dissertation, Department of Water Resources Engineering, University of Dar es Salaam, Tanzania.

Kelter PB, Grundman J, Hage D, Carr JD (1997). A discussion of water pollution in the U.S. and Mexico: with High School Lab. Activities for analysis of Lead, Atrazine and Nitrate. J. Chem. Educ. 74(12):14131421.

Konig A, Pearson HW, Silva SA (1987). Ammonia toxicity to algae growth in waste stabilization ponds. Water Sci. Technol., 19(12): 115 122.

Krkosek WH, Ragush C, Boutilier L, Sinclair A, Krumhansl K, Gagnon GA, Jamieson RC, Lam B (2012). Treatment performance of wastewater stabilization ponds in Canada's Far North, Cold Regions Engineering. Am. Soc. Civ. Eng. 612-622.

Manyama M (2005). Effect of pre-treatment on nitrogen removal in subsurface gravel bed constructed wetland. MSc (Water Resources Eng) dissertation, Department of Water Resources Engineering, University of Dar es Salaam, Tanzania.

Mara D (2005). Pond process design - a practical guide. In Shilton, A. (Ed.). Pond treatment technology. London, UK: IWA Publishing. pp. 168-187.

Mara D, Johnson M (2006). Aerated rock filters for enhancing ammonia and faecal colifom removal from facultative pond effluents. J. Environ. Eng. Div. Am. Soc. Civ. Eng. 132(4):574-577.

Mayo AW (1995). Physical - Chemical factors influencing growth and mortality of micro-organisms in oxidation ponds, Ph.D. Thesis, Tohoku University, Japan.

Mayo AW, Bigambo T (2005). Nitrogen transformation in horizontal subsurface flow constructed wetlands I: Model development. Phys. Chem. Earth 30:658-667.

Mayo AW, Mutamba J (2005). Modelling nitrogen removal in a coupled HRP and unplanted subsurface flow gravel bed constructed wetlands. Phys. Chem. Earth 30: 673-679.

Mtweve A (1999). Nitrogen Transformation and Removal in Maturation Ponds, MSc Dissertation, MSc (Eng) dissertation, Department of Civil Engineering, University of Dar es Salaam, Tanzania.

Mugasa TBB (2005). Removal of organic carbon in Water hyacinths constructed wetlands. Masters of Integrated Environmental Management Dissertation, Department of Chemical and Process Engineering, University of Dar es Salaam, Tanzania.

Muraza M (2013). Modelling nitrogen transformation and removal in Mara river basin wetlands. MSc (Water Resources Eng) dissertation, Department of Water Resources Engineering, University of Dar es Salaam, Tanzania.

Mutamba J (2002). Nitrogen removal in a coupled High Rate Pond and Subsurface Gravel Bed Constructed Wetland, MSc (Water Resources Eng) dissertation, Department of Water Resources Engineering, University of Dar es Salaam, Tanzania.

Najarian TO (1984). Application of nitrogen-cycle model to Manasquan Estuary. J. Environ. Eng. Div. Am. Soc. Civil Eng. 110(1):190-207.
Orji JC, Nweke CO, Nwabueze RN, Anyanwu BN, Chigbo LO, Nwanyanwu CE (2011). Effect of abattoir wastes on ammonium and nitrite consumptions in a tropical fress water ecosystem. J. Environ. Sci, Technol. 4(6):590-600.

Osman B (1998). Modelling bacterial Removal in Waste Stabilization Ponds in Tropical Climates, MSc (Eng) dissertation, Department of Civil Engineering, University of Dar es Salaam, Tanzania.

Reed SC (1985). Nitrogen removal in wastewater stabilization ponds" J. Water Pollut. Cont. Fed. 57(1):39-45.

Rockne KJ, Brezonik PL (2006). Nutrient removal in a cold-region wastewater stabilization pond: Importance of Ammonia volatilization, J. Environ. Eng. Div. Am. Soc. Civ. Eng. 132(4):451-459.

Sedlak R (1991). Phosphorus and Nitrogen removal from municipal wastewater: Principles and practice. Lewis Publisher, xiii, pp. 224.

Senzia MA (1999). Nitrogen transformation in facultative ponds, MSc (Eng) Thesis, Department of Civil Engineering, University of Dar es Salaam, Tanzania.

Senzia MA (2003). Modelling of nitrogen transformation and removal in horizontal subsurface flow constructed wetlands during treatment of domestic wastewater, PhD Thesis, Department of Water Resources Engineering, University of Dar es Salaam, Tanzania.

Senzia MA, Mashauri DA, Mayo AW (2003). Suitability of constructed wetlands and waste stabilization ponds in wastewater treatment, Phys. Chem. Earth 28:1117-1124.

Senzia MA, Mashauri DA, Mayo AW (2004). Modelling nitrogen transformation in horizontal subsurface flow constructed wetlands planted with Phragmites Mauritianus. J. Civ. Eng. Res. Pract. 1(2): 1 15.

Senzia MA, Mayo AW, Mbwette TSA, Katima JHY, Jørgensen SE (2002). Modelling nitrogen transformation and removal in primary facultative ponds, Ecol. Model. 154:207-215.

Shilton A, Walmsley $N$ (2005). Introduction to pond treatment technology. In Shilton, A. (Ed.). Pond treatment technology. London, UK: IWA Publishing. pp. 1-13.

Shin HK, Polprasert C (1988). Ammonia nitrogen removal in attached growth ponds. J. Environ. Eng. Div. Am. Soc. Civ. Eng. 114(4):846 863.

Showers WJ, Williams CM, Jennings GD (2006). Impact of large poultry operations on groundwater: Stable ${ }^{15} \mathrm{~N}$ isotopes of nitrate assessment. Int. J. Poult. Sci. 5:318-329.

Somiya I, Fujii S (1984). Material balances of organic and nutrients in oxidation ponds. Water. Res. 18(3):325-333

Standard Methods for the Examination of Water and Wastewater (1996). APHA, AWWA, WPCF, $19^{\text {th }}$ Edition. Washington D.C.

Stratton FE (1969). Ammonia nitrogen losses in alkaline water impoundment. J. Sanit. Eng. Div. Am. Soc. Civ. Eng. 94(SA6).

Tadesse I, Green FB, Puhakka JA (2004). Seasonal and diurnal variations of pond temperature, $\mathrm{pH}$ and dissolved oxygen in advanced integrated wastewater pond systems treating tannery effluent. Water Res. 38:645-654.

Thirumurthi D (1969). Design principles of waste stabilization ponds. J. Environ. Eng. Div. Am. Soc. Civ. Eng. 95(SA2):311-330.

Vera I, Saez K, Vidal G (2013). Performance of 14 full-scale sewage treatment plants: Comparison between four aerobic technologies regarding effluent quality, sludge production and energy consumption. Environ. Technol. 1-9.

Zimmo O, van der Steen N, Gijzen H (2005). Effects of organic surface load on process performance of pilot-scale algae and duck-weed waste stabilization ponds. J. Environ. Eng. Div. Am. Soc. Civ. Eng. 131(4):587-594. 